\title{
Significant Increase in Nutrient Stocks Following Phragmites australis Invasion of Freshwater Meadow Marsh but Not of Cattail Marsh
}

\author{
Sarah Yuckin and Rebecca Rooney* \\ Department of Biology, University of Waterloo, Waterloo, ON, Canada
}

Invasive species are a threat to biodiversity and can cause ecological degradation, however, well-established invasive species may serve valuable ecological functions. For example, in the Laurentian Great Lakes, where nutrient pollution is a major issue, highly productive Phragmites australis (European Common Reed) may provide a nutrient retention service. Yet there is a lack of research comparing carbon and macronutrient stocks in $P$. australis with resident plant communities, such as cattail and meadow marsh.

OPEN ACCESS

Edited by:

Colin McCarter,

University of Toronto

Scarborough, Canada

Reviewed by:

Md Nazim Uddin,

Saitama University, Japan

Peng Lin,

Texas A\&M University at Galveston,

United States

*Correspondence:

Rebecca Rooney

rrooney@uwaterloo.ca

Specialty section:

This article was submitted to

Biogeochemical Dynamics,

a section of the journal

Frontiers in Environmental Science

Received: 12 March 2019

Accepted: 26 June 2019

Published: 11 July 2019

Citation:

Yuckin S and Rooney R (2019)

Significant Increase in Nutrient Stocks

Following Phragmites australis

Invasion of Freshwater Meadow Marsh but Not of Cattail Marsh.

Front. Environ. Sci. 7:112.

doi: 10.3389/fenvs.2019.00112
We quantified the effect of $P$. australis invasion on carbon and macronutrient standing stocks in a freshwater coastal marsh by comparing the above- and belowground biomass, tissue nutrient concentrations, and annual nutrient standing stocks in marsh invaded by $P$. australis with cattail marsh (dominated by Typha spp.) and meadow marsh (dominated by Calamagrostis canadensis), which are being displaced by $P$. australis in Lake Erie coastal marsh. We conclude that the effect of $P$. australis invasion on carbon and macronutrient standing stocks is dependent on the plant community being replaced. The annual standing stock of carbon, nitrogen, phosphorus, and potassium are consistent between cattail marsh and $P$. australis-invaded marsh, though cattail marsh contains more magnesium (112\% mean increase) and calcium (364\% mean increase). In contrast, when $P$. australis replaces meadow marsh, the standing stocks of all measured nutrients and carbon increase significantly (103-188\% mean increase). Our study highlights that plant invasions may create trade-offs between ecosystem services. In our case, the increase in nutrient standing stocks when $P$. australis invades meadow marsh should be weighed against the documented reductions in biodiversity and habitat value.

Keywords: Canada bluejoint, cattail marsh, common reed, exotic species, invasive species, meadow marsh, nutrient retention, nutrient stocks

\section{INTRODUCTION}

Invasive species are considered a major threat to biodiversity and a driver of ecological degradation (Zedler and Kercher, 2005; Simberloff, 2011). Recent research, however, has found evidence that invasive species can provide ecological functions equal to or greater than those provided by native species (Norkko et al., 2012; Bertness and Coverdale, 2013; Grutters et al., 2015) and may even lead 
to increased local and regional biodiversity (Sax and Gaines, 2003). Recognition of the potential for invasive species to provide ecological functions has led to debate about whether conservation objectives should include the eradication of all invasive species (Schlaepfer et al., 2011, 2012; Vitule et al., 2012). It has been proposed that the decision to control invasive species should be made on a case-by-case basis through evaluation of the impact of a given invasive species on ecological function (Hershner and Havens, 2008; Hobbs et al., 2009; Davis et al., 2011).

Throughout North America, the invasive lineage of Phragmites australis (hereafter $P$. australis) is increasing in abundance and distribution (Catling and Mitrow, 2011). For example, in Lake Erie coastal marsh, P. australis took advantage of historically low lake levels during the 1990s (Tulbure et al., 2007; Tulbure and Johnston, 2010) and increased nutrient loading in the watershed (Croft and Chow-Fraser, 2007) to rapidly expand, primarily replacing cattail marsh (dominated by Typha spp.) and rare "Graminoid Coastal Meadow Marsh" (Imperiled [S2]; Ministry of Natural Resources Forestry, 2018; dominated by Calamagrostis canadensis) (Wilcox et al., 2003). These resident plant communities are naturally stratified by water depth with cattail marsh in deeper water $(11-52 \mathrm{~cm})$ and meadow marsh in shallower water $(0-27 \mathrm{~cm}$; Supplementary Materials 1), indicating the relatively broader niche of invasive $P$. australis.

Phragmites australis forms dense monocultures that replace resident plant communities (Keller, 2000; Mal and Narine, 2004; Tulbure et al., 2007) and can negatively affect wetland birds (Robichaud and Rooney, 2017), amphibians (Greenberg and Green, 2013), and turtles (Bolton and Brooks, 2010; Markle et al., 2018). The stem density of $P$. australis typically increases with age (Rooth et al., 2003), and while these negative effects on wildlife are reported from dense, established $P$. australis stands (e.g., 100 live stems $\mathrm{m}^{-2}$ ), some research suggests that at lower densities $P$. australis can provide habitat value (Meyer et al., 2010; Kiviat, 2013).

There is also evidence that $P$. australis invasion may affect nutrient and carbon cycling (Rothman and Bouchard, 2007; Windham and Ehrenfeld, 2013) as a result of high net primary production (Windham, 2001; Rothman and Bouchard, 2007; Duke et al., 2015), high rates of carbon assimilation (Farnsworth and Meyerson, 2003; Tho et al., 2016) and high nitrogen content in its foliar tissues (Findlay et al., 2002; Hirtreiter and Potts, 2012). Indeed, in its native range, $P$. australis is often used in constructed wetlands to remove nutrient pollution (Gumbricht, 1993; Bhatia and Goyal, 2014), suggesting it could provide an important water quality improvement function where it has invaded. Yet, despite the importance of carbon and macronutrients phosphorus, potassium, calcium, and magnesium (Ehrenfeld, 2010), research on P. australis invasion and its effects on nutrient stocks in freshwater coastal marsh has primarily focused on nitrogen (but see Findlay et al., 2002; Ouellet-Plamondon et al., 2004). In addition, prior work has focused on differences between Typha spp. and P. australis (e.g., Findlay et al., 2002; Farnsworth and Meyerson, 2003; Hirtreiter and Potts, 2012), ignoring critically imperiled meadow marsh, which differs markedly in vegetation diversity and physical structure from stands of $P$. australis and Typha spp.

Given that climate change and eutrophication are two immense environmental threats facing Lake Erie (Watson et al., 2016; Environment and Climate Change Canada and the U.S. Environmental Protection Agency, 2017; Jarvie et al., 2017) the capacity of a marsh plant, regardless of its origin, to take up and store carbon and macronutrients represents a critically important ecosystem function. With the limited success (Lombard et al., 2012; Quirion et al., 2018) and high costs (Martin and Blossey, 2013) of P. australis control in North America, quantifying the ecosystem functions provided by $P$. australis should inform decision makers considering whether to attempt its eradication.

We therefore sought to evaluate the influence of $P$. australis invasion on carbon and macronutrient standing stocks, including nitrogen, phosphorus, calcium, magnesium, and potassium. Further, we aimed to contrast this effect in areas where $P$. australis is displacing cattail marsh with areas where meadow marsh is being displaced. Thus, we compared standing crop above- and belowground biomass, tissue nutrient concentrations, and annual nutrient standing stocks in marsh invaded by $P$. australis with marsh dominated by Typha spp. or by $C$. canadensis (Canadian bluejoint grass). Because wetland plants can carry out luxury consumption of nutrients (Gumbricht, 1993 and references therein), we contrasted the three vegetation communities in two adjacent marshes, one with higher soil nutrients than the other. Because emergent vegetation may allocate more resources to aboveground biomass in deeper water (Wetzel and van der Valk, 2005; Duke et al., 2015), we also evaluated sites spanning a range in water depth. We hypothesized that, due to the high net primary production, foliar chlorophyll and nitrogen content of P. australis (Windham, 2001; Rothman and Bouchard, 2007; Duke et al., 2015), invaded areas would support higher carbon and nutrient standing stocks and tissue carbon and nutrient concentrations (Findlay et al., 2002; Hirtreiter and Potts, 2012). We also hypothesized that tissue concentrations and standing crop biomass would be greater in areas with more plentiful soil nutrients. Lastly, we hypothesized that standing crop biomass would be greater in deeper water.

\section{METHODS}

\section{Study Area}

We conducted the study in freshwater coastal marshes within the Long Point peninsula ( $42^{\circ} 34^{\prime} \mathrm{N}, 80^{\circ} 24^{\prime} \mathrm{W}$ ), a $35 \mathrm{~km}$ long sandspit formation located on the north shore of Lake Erie, Ontario. We sampled in the Big Creek National Wildlife Area and Long Point Provincial Park management units (Figure 1). The Long Point peninsula constitutes more than $70 \%$ of the remaining intact coastal marsh on the north shore of Lake Erie (Ball et al., 2003) and is designated as a Ramsar wetland and an UNESCO World Biosphere Reserve. Over the past 30 years, resident coastal marsh communities in this area have been increasingly replaced by invasive $P$. australis (Wilcox et al., 2003; Jung et al., 2017). 


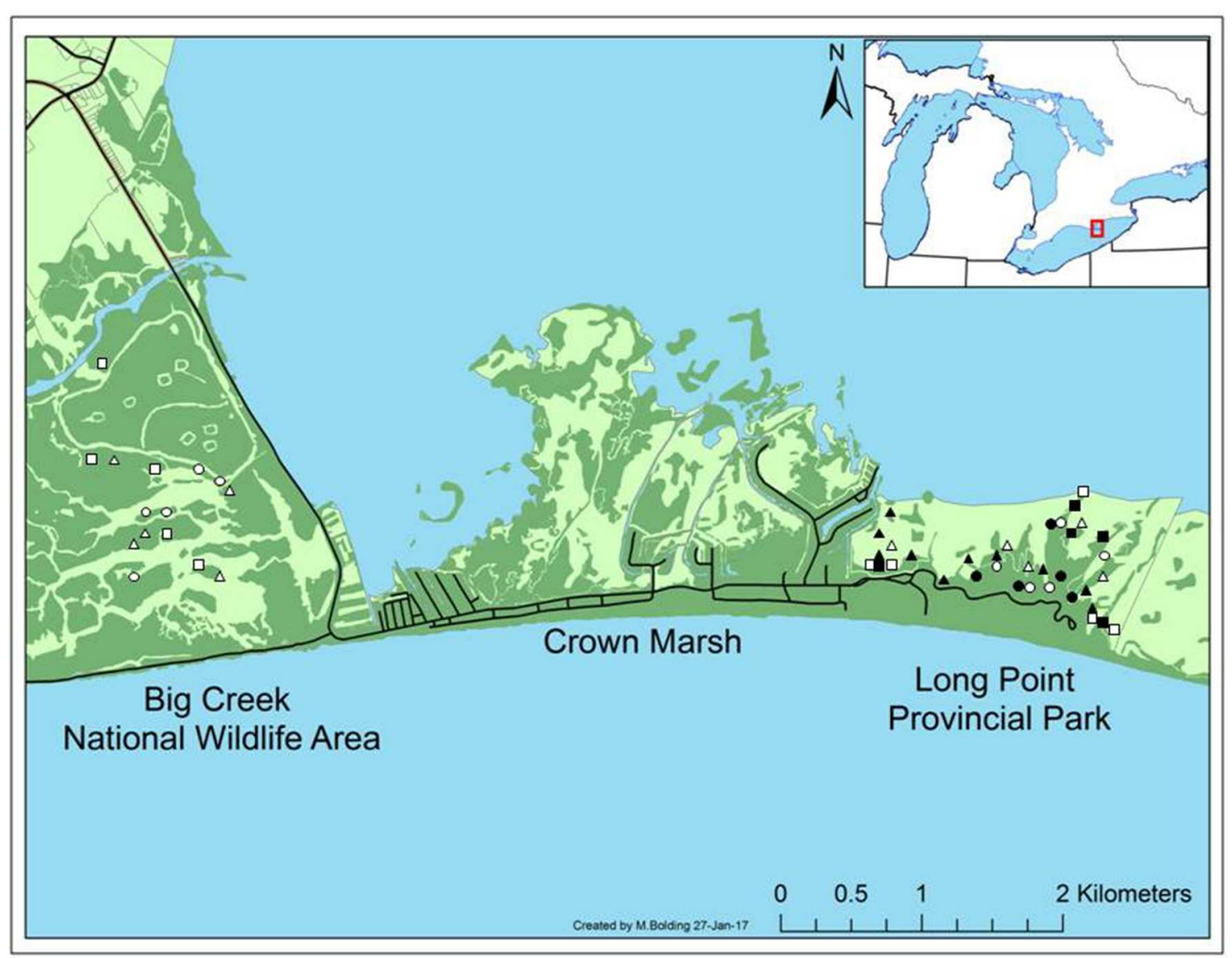

FIGURE 1 | Study location in the Big Creek National Wildlife Area $\left(42^{\circ} 35^{\prime} \mathrm{N}, 80^{\circ} 27^{\prime} \mathrm{W}\right.$ ) and Long Point Provincial Park $\left(42^{\circ} 34^{\prime} \mathrm{N}, 80^{\circ} 22^{\prime} \mathrm{W}\right)$ management units of the Long Point peninsula. Circles are meadow marsh sites, squares are cattail marsh sites, and triangles are $P$. australis-invaded sites. Black symbols were sampled in 2017, white symbols were sampled in 2016.

\section{Experimental Design}

In 2016, we evaluated the influence of soil nutrient conditions by comparing carbon and macronutrient pools and tissue concentrations among three vegetation community types ( $P$. australis-invaded marsh, cattail marsh and meadow marsh) between two regions of the Long Point peninsula that have differing soil nutrient levels (Table 1, Supplementary Materials 1). In this experiment, we measured nutrient concentrations in plant tissues, as well as above and belowground biomass from 15 sites in the Big Creek National Wildlife Area (higher nutrient environment) and 15 sites in the Long Point Provincial Park (lower nutrient environment; Figure 1). The Big Creek National Wildlife Area is located in a drainage basin that is $71.1 \%$ agricultural land cover (Essex Region Conservation Authority, 2013) and receives substantial amounts of phosphorus and nitrate from the Big Creek tributary; phosphorus levels within the marsh were above the Provincial Water Quality Objectives ( $>0.03 \mathrm{mg} / \mathrm{L})$ although nitrate levels were below the Canadian Environmental Quality Guidelines ( $<2.93$ mg/L; Essex Region Conservation Authority, 2013). In contrast, Long Point Provincial Park, which is approximately four kilometers away, is located on nutrient poor sand substrate. Regardless of vegetation community type, sites in the Big Creek National Wildlife Area consisted of taller, lower diversity plant communities growing in deeper water than sites in the Long Point Provincial Park (Table 1).

In 2017, we evaluated the influence of water depth by comparing carbon and macronutrient pools and tissue concentrations among the same three vegetation community types spanning a gradient in lake water depth. In this experiment, we measured plant tissue levels and plant biomass in 20 sites in the Long Point Provincial Park (10 P. australis-invaded sites and 10 uninvaded sites: 5 shallower meadow marsh sites and 5 deeper cattail marsh sites). The invaded and uninvaded sites were selected to be paired by May water depth to span a common gradient $(14-56 \mathrm{~cm})$. Note we also measured water depth at each site in July because seasonal water depth changes could differ among vegetation community types.

In both experiments, we selected a focal species to represent each community to characterize nutrient stocks in the three vegetation community types. These focal species were $P$. australis, C. canadensis, and Typha spp. for the P. australis-invaded, 
TABLE 1 | Average site characteristics of meadow, cattail, and $P$. australis-invaded marsh, based on measurements from three quadrats per site.

\begin{tabular}{|c|c|c|c|c|c|c|c|}
\hline Site characteristic & $\begin{array}{l}\text { Plant } \\
\text { community } \\
\text { type }\end{array}$ & \#Sites & July water depth (cm) & Canopy height (cm) & Living (stems $/ \mathrm{m}^{2}$ ) & Living ( $\%$ cover) & Species richness \\
\hline \multirow{3}{*}{$\begin{array}{l}2016 \text { Big Creek } \\
\text { National Wildlife Area }\end{array}$} & Meadow & 5 & $20.5( \pm 6.0)$ & $178( \pm 13)$ & $837( \pm 165)$ & $81( \pm 8)$ & $3.2( \pm 5.7)$ \\
\hline & Cattail & 5 & $15.5( \pm 3.0)$ & $276( \pm 30)$ & $47( \pm 6)$ & $74( \pm 10)$ & $3.0( \pm 2.1)$ \\
\hline & P. australis & 5 & $20.5( \pm 2.0)$ & $409( \pm 29)$ & $59( \pm 18)$ & $81( \pm 6)$ & $2.6( \pm 2.2)$ \\
\hline \multirow{3}{*}{$\begin{array}{l}2016 \text { Long Point } \\
\text { Provincial Park }\end{array}$} & Meadow & 5 & $2.5( \pm 3.5)$ & $101( \pm 16)$ & $802( \pm 284)$ & $65( \pm 3)$ & $14.4( \pm 1.1)$ \\
\hline & Cattail & 5 & $14.5( \pm 3.5)$ & $265( \pm 7)$ & $71( \pm 45)$ & $70( \pm 7)$ & $3.4( \pm 1.0)$ \\
\hline & $P$. australis & 5 & $15.5( \pm 9.0)$ & $319( \pm 27)$ & $125( \pm 53)$ & $78( \pm 7)$ & $5.8( \pm 1.8)$ \\
\hline \multirow{3}{*}{$\begin{array}{l}2017 \text { Long Point } \\
\text { Provincial Park }\end{array}$} & Meadow & 5 & $17.5( \pm 7.0)$ & $102( \pm 26)$ & $776( \pm 160)$ & $59( \pm 14)$ & $11.4( \pm 4.4)$ \\
\hline & Cattail & 5 & $41.0( \pm 8.5)$ & $266( \pm 14)$ & $83( \pm 66)$ & $63( \pm 9)$ & $3.0( \pm 1.9)$ \\
\hline & P. australis & 10 & $36.0( \pm 10.5)$ & $350( \pm 48)$ & $91( \pm 48)$ & $80( \pm 9)$ & $3.7( \pm 2.5)$ \\
\hline
\end{tabular}

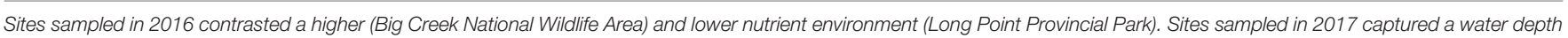
gradient in the lower nutrient environment. Standard deviation in brackets.

meadow marsh and cattail marsh communities, respectively. This approach is justified by the low evenness of these communities, wherein $50 \%$ or more of total plant cover comes from the selected focal species (Figure 2). Notably, evenness in meadow marsh in the Big Creek National Wildlife Area was lower than in meadow marsh from the Long Point Provincial Park, with the C. canadensis comprising $80 \%$ or more of total plant cover in Big Creek vs. $59-65 \%$ in Long Point (Table 1).

Typha latifolia, Typha angustifolia, and Typha $\times$ glauca are known to occur in the Long Point area (Freeland et al., 2013), but due to hybridization and extensive back-crossing with parental species, they are not reliably separable in the field (Kirk et al., 2011). Based on morphological characteristics and growth form (Swearingen et al., 2012), we determined that the $P$. australis in our study was all the non-native European lineage rather than the native North American lineage. This assessment was supported by prior genetics work in our study area, which concluded that $90 \%$ of the $P$. australis stands tested were the non-native lineage (Wilcox et al., 2003).

\section{Measuring Biomass and Leaf:Shoot Mass Ratios}

To standardize the vegetation sampling time, we sampled above and belowground biomass during the period of peak seasonal aboveground biomass. Because this can vary year to year, we established the timing of peak aboveground biomass in 2016 and 2017 independently. To determine the timing of peak aboveground biomass we clipped all live rametes from three replicate $0.25 \mathrm{~m}^{2}$ quadrats in meadow, cattail and $P$. australis-invaded sites every 10 days during the growing season. Clipped tissues were air dried for $48 \mathrm{~h}$ and then weighed. Biomass plateaued around 16 August in 2016 and 22 July in 2017. At this time, we carried out extensive sampling of aboveground and belowground standing crop biomass.

Because all three focal species are rhizomatous perennials, we employed a modified soil ingrowth method (Neill, 1992) to restrict belowground biomass collection to the current season's growth. We removed soil cores $(11.3 \mathrm{~cm}$ deep by $4.8 \mathrm{~cm}$ diameter) and replaced them with an artificial growth medium at each sampling location (Figure 1). This depth was selected to capture the peak rooting depth for each of the vegetation communities, though it likely did not capture all root and rhizome growth. Belowground biomass measurements in our study thus reflect the annual belowground biomass production within the upper $11.3 \mathrm{~cm}$ of soil.

In 2016, to compare the higher (Big Creek) and lower (Long Point Provincial Park) nutrient environments, we installed 5 replicate cores made of a mixture of sand and peat in early May at each site and retrieved them during peak aboveground biomass (August 16-19) for a 91-99 day incubation period. We then removed all roots, rhizomes, and shoots (live and dead) from the cores and oven dried them at $100^{\circ} \mathrm{C}$ for $48 \mathrm{~h}$ before weighing them to the nearest $0.01 \mathrm{~g}$ (Advanced Balance PB602-S, Mettler Toledo, ON, Canada).

In 2017 to evaluate the influence of water depth, we installed 7 replicate cores made of vermiculite at each sample site in Long Point Provincial Park, and then retrieved them during peak aboveground biomass (July 22-25) for a 60-65 day incubation period. This shorter incubation period was due to earlier onset of peak aboveground biomass in 2017. As in 2016, we removed, dried and weighed all roots, rhizomes, and shoots from the cores, but due to oven availability, the drying temperature in 2017 was reduced to $80^{\circ} \mathrm{C}$. Though the 2 years were not directly compared, we note that the differences in incubation period and drying oven temperature did not result in a significant difference in belowground biomass when we compared Long Point Provincial Park samples collected in 2016 with those from 2017 (Tables S2a,b).

We measured the aboveground biomass from each vegetation community type following the same schedule as ingrowth core retrieval. At each site (Figure 1), we randomly deployed three $0.25 \mathrm{~m}^{2}$ quadrats and harvested all aboveground living tissues by clipping vegetation just above the sediment (including all plant species in a quadrat, not simply the focal species). We then dried 


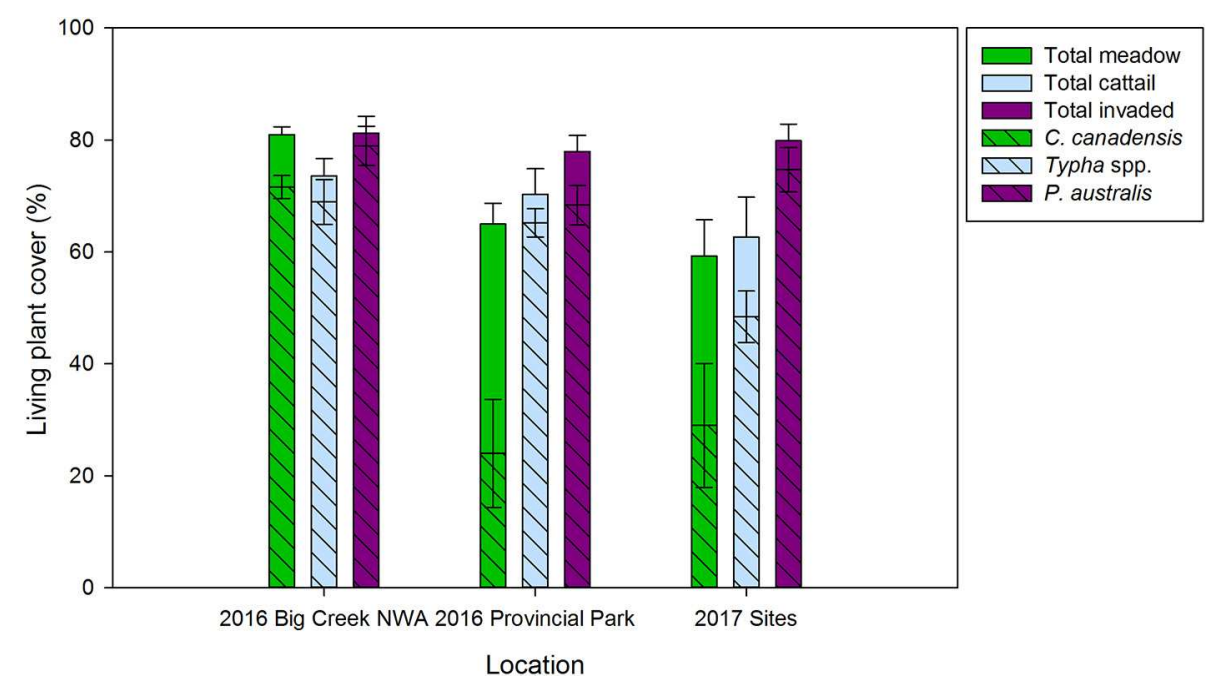

FIGURE 2 | Comparison of mean total living plant cover and mean cover of the dominant focal species (C. canadensis, Typha spp., and P. australis, in meadow marsh, cattail marsh, and P. australis invaded marsh, respectively) in a higher nutrient (Big Creek) and lower nutrient (Long Point) environment. Bars from July 2016 average across five sites per nutrient environment, whereas sampling in 2017 in the Long Point Provincial Park covered a common gradient in water depth between resident communities [meadow $(n=5)$ and cattail $(n=5)$ ] and $P$. australis invaded marsh $(n=10)$. Standard error bars shown.

and weighed all aboveground tissues following the same protocol as for belowground tissues.

In addition, in 2017, we determined the mass ratio of leaf tissues to stem tissues for the focal species at each sample site. Deploying a fourth $0.25 \mathrm{~m}^{2}$ quadrat randomly at each site, we harvested all the $P$. australis rametes from $P$. australis invaded sites, the Typha spp. rametes from cattail marsh sites, and the $C$. canadensis rametes from meadow marsh sites. We then separated the leaf and shoot tissues and dried these for $48 \mathrm{~h}$ at $80^{\circ} \mathrm{C}$ before weighing them to the nearest $0.01 \mathrm{~g}$ (Advanced Balance PB602-S, Mettler Toledo, ON, Canada). From the resulting data, we calculated the average leaf to stem mass ratio for each focal species.

\section{Plant and Soil Nutrients}

In August 2017, we revisited the 2016 sample sites that had the highest, median, and lowest total biomass from each plant community in Big Creek and Long Point $(n=18)$ and collected soil samples using a $11.3 \mathrm{~cm}$ deep corer. We dried the samples at $35^{\circ} \mathrm{C}$ for 1 week, and then sieved samples through a $2 \mathrm{~mm}$ screen to remove roots. We sent the sieved soil samples to the Agriculture and Food analytical services laboratory at the University of Guelph for determination of total nitrogen, total carbon, and plant available phosphorus, potassium, magnesium and calcium. Total nitrogen and carbon were measured using thermal conductivity detection, plant available phosphorus was extracted using sodium bicarbonate (Reid, 1998), and the other nutrients were extracted using ammonium acetate prior to measurement with mass spectrometry (Simard, 1993; Agriculture and Food Laboratory University of Guelph, 2017).

In July 2016, during peak aboveground biomass, we collected leaf, stem, and below ground tissues from our focal species in ten sites from each of the meadow marsh, cattail marsh, and $P$. australis-invaded marsh communities in Big Creek and Long Point Provincial Park. We oven-dried the tissues at $100^{\circ} \mathrm{C}$ for $48 \mathrm{~h}$, homogenized and then submitted them to the Agriculture and Food Laboratory at the University of Guelph for measurement of total nitrogen and carbon (\% dry weight), using thermal conductivity detection (Reid, 1998) and total phosphorus, potassium, magnesium and calcium (\% dry weight), using mass spectrometry.

\section{Nutrient Standing Stocks}

Using the carbon and macronutrient concentrations for different tissue types, we estimated annual nutrient standing stocks (in $\mathrm{g} \mathrm{m}^{-2}$ ) characteristic of the $P$. australis-invaded, cattail, and meadow marsh community types. To achieve this, we multiplied tissue nutrient concentrations ( $\%$ dry weight) by the above and belowground biomass weights of the total community $\left(\mathrm{g} \mathrm{m}^{-2}\right.$ dry weight) and the leaf: stem and root: shoot mass ratios for the focal species. Note that this approach assumes all the plant biomass in a community has the same tissue nutrient levels and tissue mass ratios as the focal species. The validity of this assumption is greater for cattail marsh and P. australis-invaded marsh than for meadow marsh in Long Point Provincial Park (Figure 2). As a sensitivity analysis, we also estimated nutrient standing stocks $\left(\mathrm{g} \mathrm{m}^{-2}\right)$ of only the focal species in their respective communities, excluding biomass attributable to other co-occurring species. Based on this comparison, the assumption that all biomass in our samples came from the focal species did not sway our conclusions.

\section{Statistical Analysis}

To test for differences in aboveground biomass, belowground biomass, total biomass, and root: shoot mass ratios among $P$. australis-invaded, emergent cattail and meadow marsh habitats, 
we used general linear models. All the model forms we tested are defined in Table 2. To meet normality assumptions, we squareroot transformed belowground biomass $\left(\mathrm{g} \mathrm{m}^{-2}\right)$ and root: shoot ratio, and log-transformed magnesium $\left(\mathrm{g} \mathrm{m}^{-2}\right)$ and calcium $(\mathrm{g}$ $\mathrm{m}^{-2}$ ). All general linear models were calculated using the " $\mathrm{lm}$ " function from the "stats" package (R Core Team, 2016). Even if interaction terms were non-significant, we retained them in our final models if the model itself had a good fit. To determine the best fit for the 2017 biomass response variable, we used the "AICc" function in the "MuMIn" package (Barton, 2018). Significant differences in response variable among treatments were determined at $p<0.05$, and we performed all statistical tests using R Studio (R Core Team, 2016). We interpreted the model fit to be strong at the arbitrary threshold where $R^{2} \geq 0.6$.

To test for the effect of soil nutrient availability on any differences in these response variables among vegetation community types, we used the 2016 samples to cross vegetation community type with soil nutrient level, comparing the high nutrient (Big Creek NWA) and low nutrient (Long Point Provincial Park) environments and included their interaction (Table 3).

To test for an effect of water depth on any differences in these response variables among vegetation community types, we used the 2017 samples from Long Point Provincial Park to include water depth as a covariate (Table 4). Because the water depths measured at each site in May differed from the July measurements, we tested general linear models for each response variable using both measurement dates and selected the measurement date generating the lowest Akaike's Information Criterion (corrected for small sample size) as our final model.

Next, we used a general linear model to test whether soil nutrients differed significantly between the Big Creek NWA and the Long Point Provincial Park, combining the three vegetation

TABLE 2 | General linear model fit tests for 2016 and 2017 biomass response variables ( $\mathrm{g} \mathrm{m}^{-2}$ aboveground, belowground, total biomass, root: shoot), soil nutrient concentration (total carbon, total nitrogen and plant available phosphorus, potassium, magnesium, and calcium), tissue carbon and macronutrient concentrations (\% dry weight of carbon, nitrogen, phosphorus, potassium, magnesium, and calcium), and carbon and macronutrient standing stock ( $\mathrm{g} \mathrm{m}^{-2}$ of carbon, nitrogen, phosphorus, potassium, magnesium, and calcium).

\begin{tabular}{|c|c|}
\hline $\begin{array}{l}\text { Response } \\
\text { variable }\end{array}$ & Model \\
\hline 2016 Biomass & $\begin{aligned} y & =\beta 0+\beta 1 \text { plant community }+\beta 2 \text { nutrient environment } \\
& +\beta 3 \text { (plant community * nutrient environment) }\end{aligned}$ \\
\hline 2017 Biomass & $\begin{aligned} y & =\beta 0+\beta 1 \text { plant community }+\beta 2 \text { water depth gradient } \\
& +\beta 3 \text { (plant community * water depth gradient). }\end{aligned}$ \\
\hline $\begin{array}{l}\text { Soil nutrient } \\
\text { concentration }\end{array}$ & $\begin{aligned} y & =\beta 0+\beta 1 \text { plant community }+\beta 2 \text { nutrient environment } \\
& +\beta 3 \text { (plant community * nutrient environment) }\end{aligned}$ \\
\hline $\begin{array}{l}\text { Tissue nutrient } \\
\text { concentration }\end{array}$ & $\begin{array}{l}y=\beta 0+\beta 1 \text { plant species }+\beta 2 \text { tissue type }+\beta 3 \text { (plant } \\
\text { species * tissue type) }\end{array}$ \\
\hline $\begin{array}{l}\text { Nutrient } \\
\text { standing stock }\end{array}$ & $y=\beta 0+\beta 1$ plant community \\
\hline
\end{tabular}

Plant community type refers to meadow, cattail and P. australis-invaded marsh. Nutrient environment refers to high nutrient (Big Creek National Wildlife Area) or low nutrient (Long Point Provincial Park). Plant species refers to C. canadensis, Typha spp., or P. australis. Tissue type refers to belowground, stems, or leaves. community types (Table 2). We also used general linear models to test whether differences in nutrient concentrations (\% dry weight) among focal species ( $P$. australis, Typha spp., and $C$. canadensis), plant tissue types (leaf, stem, and belowground tissue), and their interaction were significant (Table 2). Similarly, we used general linear models to test whether nutrient standing stocks $\left(\mathrm{g} \mathrm{m}^{-2}\right)$ differed among vegetation communities (meadow, cattail, and P. australis-invaded; Table 2).

\section{RESULTS}

\section{Biomass}

The models predicting biomass measurements based on plant community (meadow, cattail and $P$. australis-invaded), nutrient environment (low and high) and their interaction provided a statistically significant fit (Table 3 ). There was no significant interaction between the effect of nutrient environment and plant community on any biomass response variable (Supplementary Materials 2). The higher nutrient environment produced significantly greater aboveground

TABLE 3 | Results of general linear model fit tests for the response variables aboveground, belowground, and total live biomass, as well as root:shoot ratio.

\begin{tabular}{llrr}
\hline Response variable & $\boldsymbol{F}$-test (d.f.) & $\boldsymbol{p}$-value & $\boldsymbol{R}^{\mathbf{2}}$ \\
\hline Aboveground biomass & $23.340(5,24)$ & $<0.001$ & 0.829 \\
SQRT (Belowground biomass) & $4.252(5,24)$ & 0.007 & 0.470 \\
Total live biomass & $15.200(5,24)$ & $<0.001$ & 0.760 \\
SQRT (Root:shoot) & $6.017(5,24)$ & 0.001 & 0.556
\end{tabular}

The general model form is $y=\beta_{0}+\beta_{1}$ plant community $+\beta_{2}$ nutrient environment + $\beta_{3}$ (plant community *nutrient environment), wherein plant community refers to meadow marsh $(n=10)$, emergent cattail $(n=10)$ or P. australis-invaded marsh $(n=10)$, and nutrient environment refers to the Big Creek National Wildlife Area (higher nutrients) or the Long Point Provincial Park (lower nutrients). Belowground biomass and root to shoot ratio were square-root transformed to meet the assumption of normality (see Supplementary Materials 2 for more details).

TABLE 4 | Results of general linear model fit tests for biomass response variables, as predicted by $y=\beta_{0}+\beta_{1}$ plant community $+\beta_{2}$ water depth gradient $+\beta_{3}$ (plant community * water depth gradient).

\begin{tabular}{lllll}
\hline $\begin{array}{l}\text { Response } \\
\text { variable }\end{array}$ & $\begin{array}{l}\text { Water } \\
\text { measurement }\end{array}$ & F-test (d.f.) & $\boldsymbol{p}$-value & $\boldsymbol{R}^{\mathbf{2}}$ \\
\hline $\begin{array}{l}\text { Aboveground } \\
\text { biomass }\end{array}$ & July & $5.250(5,14)$ & 0.006 & 0.652 \\
$\begin{array}{l}\text { SQRT } \\
\text { (Belowground } \\
\text { biomass) }\end{array}$ & May & $10.080(5,14)$ & $<0.001$ & 0.783 \\
$\begin{array}{l}\text { Total live } \\
\text { biomass }\end{array}$ & July & & & \\
$\begin{array}{l}\text { SQRT } \\
\text { (Root:shoot) }\end{array}$ & May & $5.770(5,14)$ & 0.004 & 0.673 \\
\end{tabular}

Plant community refers to meadow marsh $(n=5)$, emergent cattail $(n=5)$, or $P$. australis-invaded marsh $(n=10)$. Water depth measurement date (May or July 2017) was determined from the glm producing the lower AlCc value (Supplementary Materials 2). Belowground biomass and root: shoot were square root transformed to meet the assumption of normality. See Supplementary Materials 2 for detailed results and AlCc values. 
and total biomass, though nutrient environment evidenced no significant effect on belowground biomass or root:shoot ratio (Tables S2a-f). Regardless of the nutrient environment, aboveground and total biomass were greatest in P. australisinvaded communities, intermediate in cattail marsh, and lowest in meadow marsh (Figure 3). Differences in belowground biomass and root:shoot ratio among plant communities were not statistically significant (Tables S2d,f), though cattail marsh produced more belowground biomass on average than the other two communities (Figure 3).

The models predicting biomass response variables based on plant community type (meadow, cattail and P. australis invaded), water depth, and their interaction all provided a reasonable fit with $R^{2} \geq 0.6$ (Table 4). Interestingly, both aboveground and total biomass were best predicted by July 2017 water depth measurements, tending to increase with water depth, whereas the model fit for belowground biomass and root:shoot ratio was best using May 2017 water depths (Tables S2g-n). Both belowground biomass and root:shoot ratio evidenced a significant interaction effect for cattail marsh (Tables $\mathbf{S} \mathbf{2} \mathbf{i}-\mathbf{j}, \mathbf{m}, \mathbf{n}$ ). In water depths above $40 \mathrm{~cm}$, cattail had significantly greater belowground biomass than $P$. australis invaded sites (Figure S3a), while meadow sites had the lowest belowground biomass at all water depths. Similarly, the root:shoot ratio of cattail sites was greater than the root:shoot of $P$. australis invaded sites at water depths $>40 \mathrm{~cm}$.

Given that $P$. australis invaded and resident plant community plots established in May 2017 were intentionally paired by water depth, it is not surprising that average May water depths were similar $(36 \mathrm{~cm} \pm 12 \mathrm{SD}$ in $P$. australis-invaded, $37 \mathrm{~cm} \pm$ 11 SD in resident plant communities; Figure S1a). Yet, when remeasured in July 2017, the average water depth of resident

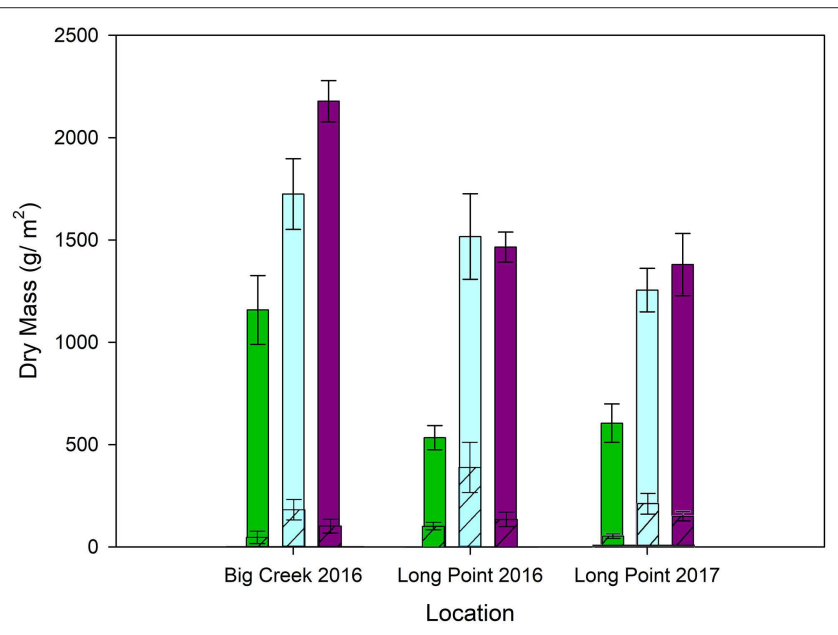

FIGURE 3 | Stacked bar graph indicating annual production as total live biomass, partitioned into aboveground (solid bars) and belowground (stripped bars) components. Bars contrast meadow marsh (green), cattail (blue) and $P$. australis-invaded plant communities (purple) in a higher nutrient (Big Creek NWA 2016) and lower nutrient (Long Point Provincial Park 2016) environment. Bars from Long Point Provincial Park 2017 average across a water depth gradient (14-56 cm water depth). Standard error bars shown. Note that belowground biomass is one growing season's production within the upper $11.3 \mathrm{~cm}$ of soil. plant community sites had decreased to an average $29 \mathrm{~cm}( \pm 14$ $\mathrm{SD})$, whereas the average water depth for $P$. australis-invaded sites was unchanged from May values $(36 \mathrm{~cm} \pm 11$ SD in July; Table S1a; Figure S1a).

\section{Plant Morphology}

Overall, there was little difference in leaf:stem ratio between $P$. australis $(0.36 \pm 0.10 \mathrm{SD})$ and $C$. canadensis $(0.33 \pm 0.08 \mathrm{SD})$. Typha spp., however, had a much higher leaf:stem ratio $(0.90 \pm$ $0.33 \mathrm{SD})$.

\section{Soil and Plant Tissue Nutrient Concentrations}

The models predicting soil carbon and macronutrient levels based on plant community (meadow, cattail and $P$. australisinvaded), the nutrient environment (low and high), and their interaction all provided a good fit with $R^{2} \geq 0.7$ (Table 5). There were no significant interactions between the influence of wetland and plant community on any of the measured soil carbon and macronutrients (Supplementary Materials 2). All measured soil carbon and macronutrients, except potassium, were significantly higher in Big Creek NWA than in Long Point Provincial Park, regardless of plant community (Supplementary Materials 2). Averaging the two nutrient environments, for the most part we detected no significant difference in soil carbon or macronutrients among the plant community types (Supplementary Materials 2), although meadow marsh in the Long Point Provincial Park generally had the lowest levels (Supplementary Materials 4). Plant available calcium was an exception, being significantly higher in the soil collected from cattail marsh than meadow marsh in Long Point Provincial Park (Supplementary Materials 4).

The models predicting plant tissue carbon and macronutrient concentrations based on plant species (C. canadensis, Typha spp., or $P$. australis), tissue type (leave, stem, or roots and rhizomes) and their interaction provided a strong fit $\left(R^{2} \geq\right.$ 0.8) for all macronutrients but not for total carbon (Table 6). This model also failed to predict nitrogen to phosphorus ratios (Table 6).

TABLE 5 | Results of general linear model fit tests for soil nutrient content in the higher nutrient Big Creek National Wildlife Area and the lower nutrient Long Point Provincial Park sites.

\begin{tabular}{lllrl}
\hline Soil carbon or macronutrient & $\boldsymbol{F}$-test (d.f.) & $\boldsymbol{p}$-value & $\boldsymbol{R}^{\mathbf{2}}$ \\
\hline Total & Nitrogen & $11.370(5,12)$ & $<0.001$ & 0.826 \\
& Carbon & $9.490(5,12)$ & $<0.001$ & 0.798 \\
Plant available & Phosphorus & $7.943(5,12)$ & 0.002 & 0.768 \\
& Potassium & $5.866(5,12)$ & 0.006 & 0.710 \\
& Magnesium & $11.920(5,12)$ & $<0.001$ & 0.832 \\
& Calcium & $10.090(5,12)$ & $<0.001$ & 0.808 \\
\hline
\end{tabular}

The general model form is predicted soil carbon and macronutrient concentration = $\beta 0+\beta_{1}$ plant community $+\beta_{2}$ nutrient environment $+\beta_{3}$ (plant community ${ }^{*}$ nutrient environment). Plant community refers to meadow marsh $(n=6)$, emergent cattail $(n=6)$, or P. australis-invaded marsh $(n=6)$ (see Supplementary Materials 2 for detailed results). 
Generally, phosphorus, potassium and magnesium in plant tissues exhibited no interaction between plant species and tissue type (Supplementary Materials 2). These were lowest in the stem tissues and higher in the leaf and belowground tissues (Figure 4). Specifically, leaf tissue contained significantly higher phosphorus and potassium, while belowground tissues had significantly higher magnesium. In addition, phosphorus and potassium concentrations differed among plant species (Supplementary Materials 2). Phosphorus and potassium levels in plant tissues also differed among species: $P$. australis tissues contained significantly more phosphorus and potassium than $C$. canadensis and significantly more potassium than Typha spp. (Figure 4, Supplementary Materials 2).

Trends with carbon, nitrogen and calcium were more complex as they exhibited significant interactions between plant species and tissue type (Supplementary Materials 2). For example, Typha spp. contained significantly more carbon in its roots and rhizomes than its leaves, whereas the other species did not exhibit differences in carbon content among tissues (Figure 4). Nitrogen was much higher in $P$. australis leaf tissue than in C. canadensis or Typha spp. leaves, but there were no differences in the nitrogen concentration of stems and belowground tissue among species (Figure 4). Calcium concentrations in Typha spp. stem tissue was much higher than in C. canadensis or P. australis, but similar calcium concentrations were present in P. australis and Typha spp. foliar tissue and C. canadensis and Typha spp. belowground tissue (Figure 4).

\section{Nutrient Standing Stocks}

The models predicting annual nutrient standing stock ( $g$ $\mathrm{m}^{-2}$ ) for carbon and the five macronutrients based on plant community type (meadow, cattail, or P. australis-invaded marsh) provided a statistically significant fit (Table 6). Overall, the stocks of carbon, nitrogen, phosphorus and potassium were lower in meadow marsh, but were equivalent in $P$. australis-invaded and emergent cattail (Figure 5, Supplementary Materials 2). Stocks of calcium and magnesium were also lowest in meadow marsh but were lower in P. australis-invaded marsh than in cattail marsh (Figure 5). We compared analyses wherein carbon and nutrient standing stocks were estimated by assuming that all species in the plot were the focal species with estimates considering only the fraction of total biomass attributable to the focal species itself (estimates in Supplementary Materials 5), but the model results were unchanged.

\section{DISCUSSION}

Invasive species may provide valuable ecological services in invaded ecosystems (Kopf et al., 2017). In the Great Lakes, where nearshore eutrophication and climate change are two of the most pressing environmental threats, a wetland plant that enhances carbon and other macronutrient assimilation could be an asset, even if it is non-native in origin. Decisions about $P$. australis control should weigh the ecological costs and benefits of invasion (Hershner and Havens, 2008; Hobbs et al., 2009; Davis et al., 2011), but a lack of research comparing nutrient pools and fluxes in habitat invaded by $P$. australis with those in the cattail
TABLE 6 | General linear model fit test results for carbon and macronutrients in plant tissue and estimated standing stocks.

\begin{tabular}{|c|c|c|c|c|}
\hline Carbon or Macronutrient & Units & $F$-test (d.f.) & $p$-value & $R^{2}$ \\
\hline Tissue carbon & $\%$ dry weight & $2.288(8,21)$ & 0.062 & 0.466 \\
\hline Tissue nitrogen & & $51.480(8,21)$ & $<0.001$ & 0.952 \\
\hline Tissue carbon:nitrogen & & $32.020(8,21)$ & $<0.001$ & 0.924 \\
\hline Tissue phosphorus & & $10.380(8,21)$ & $<0.001$ & 0.798 \\
\hline Tissue nitrogen:phosphorus & & $1.381(8,21)$ & 0.261 & 0.345 \\
\hline Tissue potassium & & $16.240(8,21)$ & $<0.001$ & 0.861 \\
\hline Tissue magnesium & & $13.490(8,21)$ & $<0.001$ & 0.837 \\
\hline Tissue calcium & & $112.500(8,21)$ & $<0.001$ & 0.977 \\
\hline Standing stock carbon & $\mathrm{g} \mathrm{m}^{-2}$ & $16.450(2,47)$ & $<0.001$ & 0.412 \\
\hline Standing stock nitroge & & $14.840(2,47)$ & $<0.001$ & 0.387 \\
\hline Standing stock phosphorus & & $14.330(2,47)$ & $<0.001$ & 0.379 \\
\hline Standing stock potassium & & $29.760(2,47)$ & $<0.001$ & 0.559 \\
\hline $\begin{array}{l}\log _{10} \text { (Standing stock } \\
\text { magnesium) }\end{array}$ & & $35.760(2,47)$ & $<0.001$ & 0.604 \\
\hline $\begin{array}{l}\log _{10} \text { (Standing stock } \\
\text { calcium) }\end{array}$ & & $150.000(2,47)$ & $<0.001$ & 0.865 \\
\hline
\end{tabular}

The general model form for plant tissue nutrient concentration (\% dry weight) is $y=\beta_{0}$ $+\beta_{1}$ plant species $+\beta_{2}$ tissue type $+\beta_{3}$ (plant species ${ }^{*}$ tissue type). Tissue types were leaf, stem or belowground tissues. Plant species were either $C$. canadensis, Typha spp., or $P$. australis. The general model form for carbon and macronutrient standing stocks ( $g$ $\left.m^{-2}\right)$ is $y=\beta_{0}+\beta_{1}$ plant community. Plant community refers to meadow marsh $(n=15)$, cattail marsh $(n=15)$, or $P$. australis-invaded marsh $(n=20)$. Standing stocks $\left(\mathrm{g} \mathrm{m}^{-2}\right)$ of magnesium and calcium were log-transformed to meet the normality assumption (see Supplementary Materials 2 for detailed results).

and meadow marsh that $P$. australis is replacing prevents such calculations. Our research addressed this gap, comparing annual plant production (above and belowground) and carbon and nutrient standing stocks in $P$. australis invaded marsh with values typical of the marsh types $P$. australis is replacing. Importantly, we also examined the effects of environmental conditions like nutrient availability and water depth, which can influence plant production and nutrient assimilation.

\section{Outcome of Invasion Contingent on Community Being Replaced}

Our most important result is arguably that when rare meadow marsh is replaced by $P$. australis, we see a major increase in plant biomass, carbon and macronutrient standing stocks. Yet, when $P$. australis replaces cattail marsh, little change in biomass, carbon or nutrient standing stocks takes place, despite significantly higher nitrogen and marginally higher phosphorus and potassium in $P$. australis leaves than in Typha spp. leaves. Indeed, the only significant difference in standing stocks between cattail marsh and $P$. australis-invaded marsh was that $P$. australisinvaded marsh had lower calcium and magnesium stocks. Our research thus emphasizes that the magnitude and direction of change in carbon and macronutrient standing stocks caused by plant invasion is contingent on the vegetation community that is being replaced. Phragmites australis invasion cannot simply be assumed to increase carbon and macronutrient assimilation in invaded coastal marsh, even on the basis of differences in tissue carbon and macronutrient concentrations. 


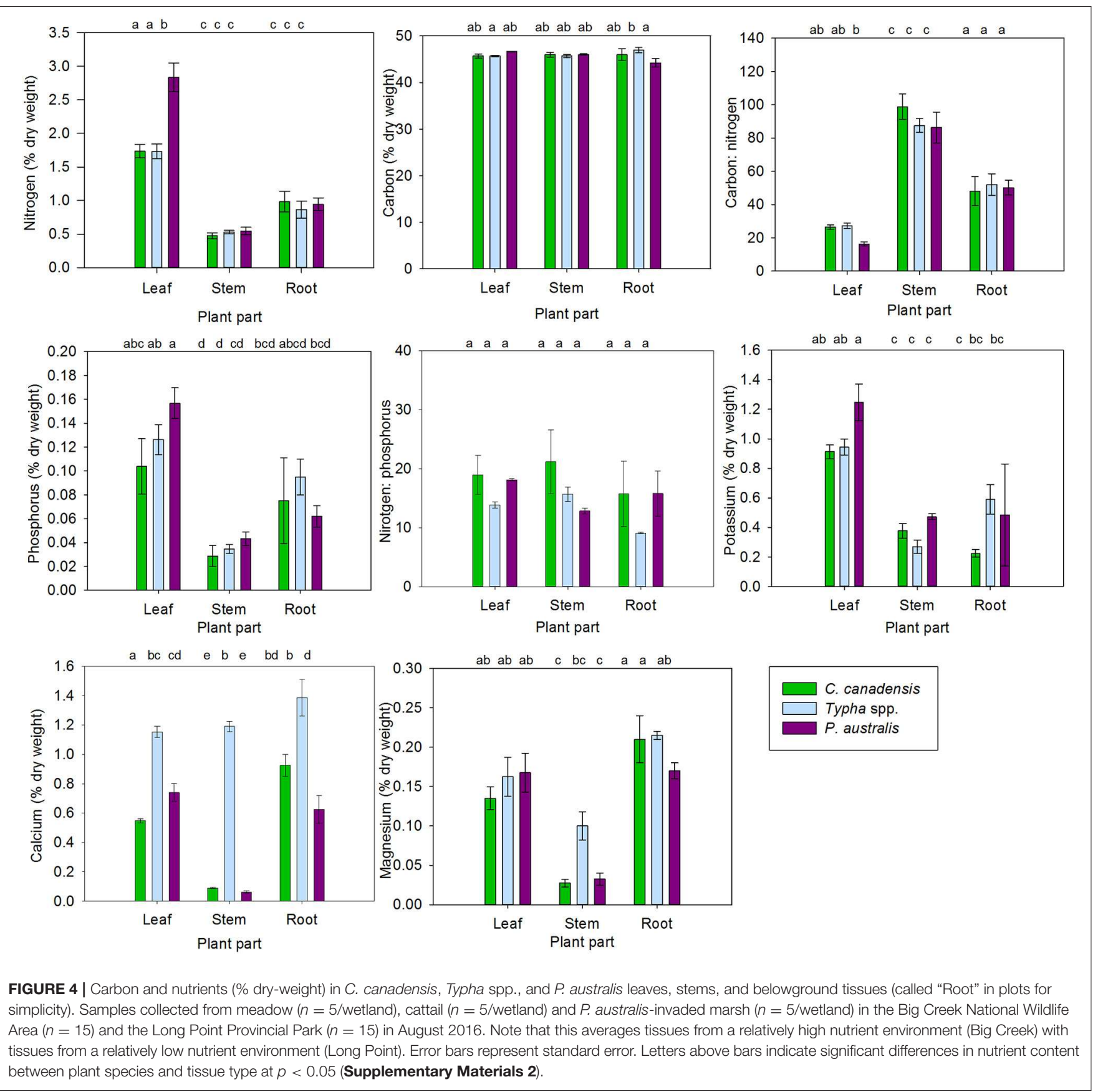

To our knowledge, no other field studies have compared $C$. canadensis carbon and macronutrient concentrations to Typha spp. or P. australis tissues, nor carbon and macronutrient stocks in meadow, with those in cattail and $P$. australis-invaded marsh. A study by Kao et al. (2003) established that C. canadensis had a low ability to assimilate nitrogen and phosphorus pollutants compared to other wetland macrophytes $\left(\sim 7 \mathrm{~g} \mathrm{~m}^{-2} \mathrm{~N}, \sim 1 \mathrm{~g}\right.$ $\left.\mathrm{m}^{-2} \mathrm{P}\right)$, suggeting that nutrient stocks may increase following $P$. australis invasion of $C$. canadensis dominated meadow marsh. Based on equivalent concentrations of carbon, phosphorus, and potassium in the tissues of C. canadensis and those of Typha spp. and $P$. australis measured in our study, this inferior nutrient assimilation is likely attributable to lower standing crop biomass in meadow marsh. Indeed, the aboveground biomass in meadow marsh reported in our study is similar to that reported in a greenhouse experiment $\left(1,057 \pm 12 \mathrm{~g} / \mathrm{m}^{2}\right.$; Ouellet-Plamondon et al., 2004), and lies well below the standing crop biomass values for cattail marsh and $P$. australis-invaded marsh.

Our conclusion that $P$. australis invasion in cattail marsh does not increase nutrient stocks conflicts with some published studies. For example, Findlay et al. (2002) reported that $P$. australis retained almost two times more nitrogen than Typha 

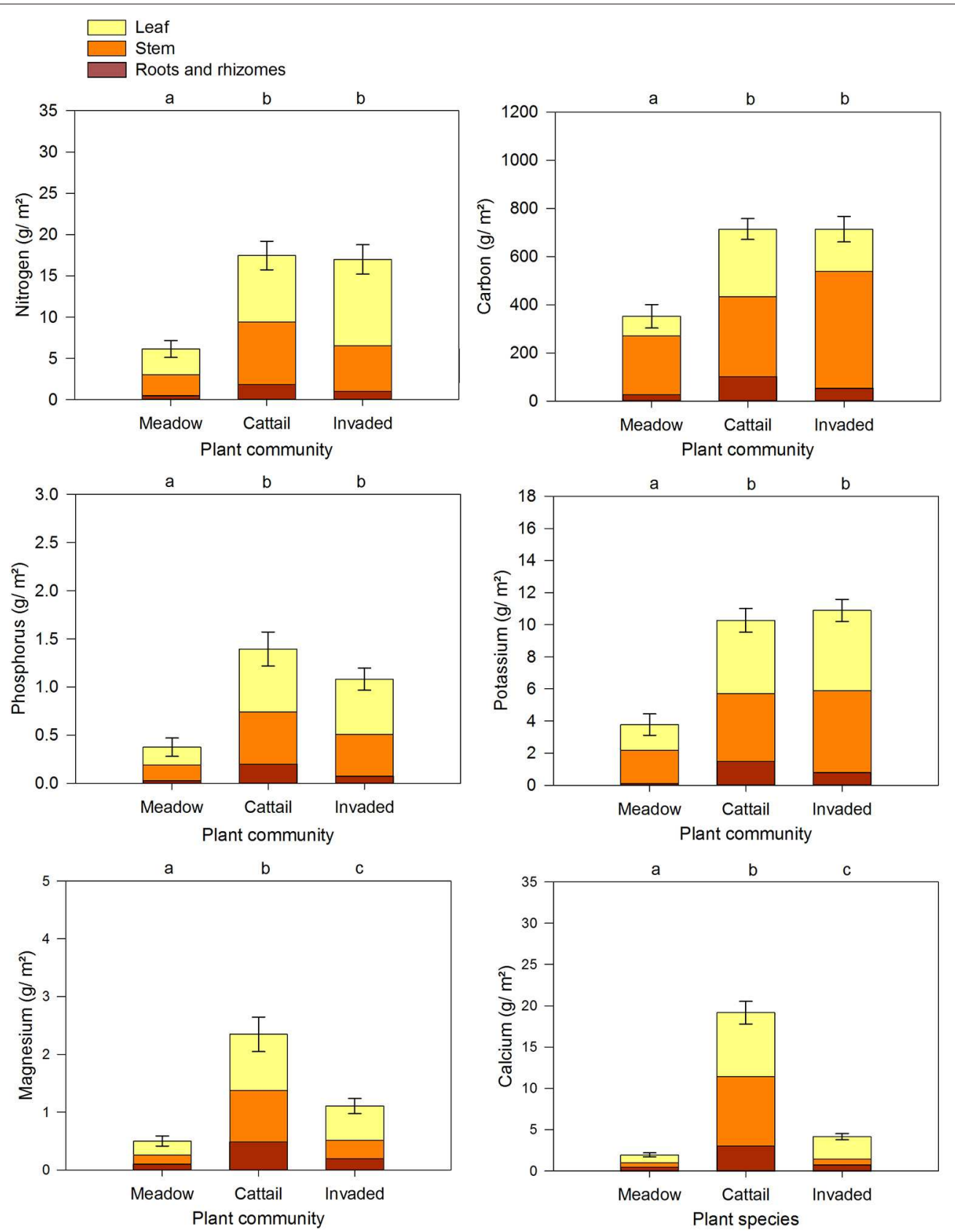

FIGURE 5 | Estimated annual carbon and nutrient standing stocks in the three plant community types broken down by tissue type. The values combine 2016 samples from the Big Creek National Wildlife Area $(n=5$ each from meadow, cattail, and P. australis-invaded marsh) and the Long Point Provincial Park ( $n=5$ each from meadow, cattail, and $P$. australis-invaded marsh) with the 2017 samples from Long Point Provincial Park ( $n=5$ meadow, $n=5$ cattail, and $n=10 P$. australis invaded sites). Error bars reflect standard error in total nutrient standing stock, summed from all tissues. Letters above bars indicate significant differences among plant community types at $p<0.05$ (Supplementary Materials 2).

angustifolia in living aboveground biomass (Findlay et al., 2002). They concluded that $P$. australis had both a higher nitrogen tissue concentration and 50\% more biomass production than T. angustifolia (Findlay et al., 2002). The discrepancy between Findlay et al. (2002)'s results and ours is likely due to a focus on different species of Typha. The Typha spp. dominating cattail marsh in our study could not be identified to species by their morphology and most likely comprised the hybrid
Typha $\times$ glauca with varying degrees of backcrossing to parental T. angustifolia and T. latifolia (Freeland et al., 2013). Typha $\times$ glauca, like $P$. australis, is a highly productive, tall, clonal, non-native monocot that forms monocultures and can have a negative impact on native species diversity (Larkin et al., 2012). Consequently, the difference in nutrient assimilation by $P$. australis and cattail marsh reported by other authors might occur in study areas where $T$. angustifolia or $T$. latifolia are 
more common or when only foliar nitrogen stocks are examined (Findlay et al., 2002; Farnsworth and Meyerson, 2003; Hirtreiter and Potts, 2012).

Yet our conclusion regarding $P$. australis invasion of cattail marsh agrees with some recent field studies in the Great Lakes region (Rothman and Bouchard, 2007; Duke et al., 2015), potentially because the Typha spp. in these studies likely also included Typha $\times$ glauca. These studies reported wide ranges in aboveground biomass values that were similar to our observations (cattail: 1,661-2,930 g/m $\mathrm{m}^{2}$ and $P$. australis-invaded: 1,522-3,378 $\mathrm{g} / \mathrm{m}^{2}$; Rothman and Bouchard, 2007; Duke et al., 2015). This variation in aboveground biomass may be due to differences in water or nutrient regimes, which is why we repeated our comparisons in higher and lower nutrient environments as well as along a water depth gradient.

\section{Outcome of Invasion Depends on Nutrient Environment and Water Depth}

Invasive $P$. australis has been noted to allocate more resources to aboveground biomass in high nitrogen environments, which is believed to facilitate its spread in disturbed environments (Minchinton and Bertness, 2003). Such a response could contribute to its nutrient retention service: higher loading would trigger higher uptake, a desirable property. However, we observed that all focal species exhibited lower root:shoot ratios and higher biomass and nutrient tissue concentrations in the more nutrient rich Big Creek compared to the lower nutrient Long Point Provincial Park. This agrees with widespread studies concluding that increasing nutrient loads led to increased total biomass of vegetation, foliar nitrogen and phosphorus, and decreased root: shoot ratios (e.g., Powelson and Lieffers, 1992; Kvet et al., 2008; Rong et al., 2014; Caplan et al., 2015; Graham and Mendelssohn, 2016; Li et al., 2016). In fact, the largest difference in annual production between nutrient environments was observed in meadow marsh, not $P$. australis invaded marsh. Consequently, any nutrient retention benefit of $P$. australis invasion of meadow marsh would be minimized under high nutrient loading environments, which are the conditions under which increased nutrient stocks would be desirable. The difference in nutrient tissue concentrations between higher and lower nutrient environments could be due to either nutrient limitation in Long Point Provincial Park or luxury consumption in Big Creek NWA (e.g., Gumbricht, 1993). Regardless of mechanism, clearly nutrient loading will influence the degree to which $P$. australis invasion alters carbon and macronutrient pools in coastal marsh.

Water depth may also influence plant production and resource allocation to different tissue types, with consequences for carbon and macronutrient standing stocks. Depending on the plant species, standing crop biomass may increase, decrease or not change with water depth (e.g., Fraser and Karnezis, 2005; Miller and Zedler, 2013; Middleton et al., 2015). In a greenhouse experiment, Wetzel and van der Valk (2005) reported higher C. canadensis aboveground biomass in flooded conditions compared to well-watered and dry conditions, leading to our prediction that standing crop biomass for our focal species would increase with water depth. The response of $P$. australis biomass to water depth has been reviewed by Engloner (2009) who reported inconsistency that might be attributable to differences in water depth stability. In our study, the total biomass of $P$. australis and $C$. canadensis both increased with water depth, though a natural community turnover takes places between 30 and $40 \mathrm{~cm}$ of standing water (May measurements), where higher biomass cattail marsh replaces lower biomass meadow marsh. The relationship between cattail marsh standing crop biomass and water depth in our study is less clear, with aboveground biomass decreasing with water depth and belowground biomass increasing. In contrast, Duke et al. (2015) reported that Typha spp. aboveground biomass was positively related to water depth in a Great Lakes wetland. Our results also differ from previous studies that did not find a difference in belowground biomass between cattail and P. australis-invaded communities (OuelletPlamondon et al., 2004; Rothman and Bouchard, 2007). A major difference between our study and others examining below ground biomass in P. australis-invaded marhes (e.g., Farnsworth and Meyerson, 2003; Rothman and Bouchard, 2007) is that we used the in-growth core technique because our interest was in annual standing stocks, whereas other field studies typically used traditional soil core methods to measure total belowground standing crop biomass. Our approach would exclude any roots and rhizomes produced during previous seasons, and consequently yields lower estimates of belowground biomass than many other studies (e.g., Farnsworth and Meyerson, 2003; Ouellet-Plamondon et al., 2004; Rothman and Bouchard, 2007).

The mechanism driving the relationships between plant production and water depth are uncertain. Some studies suggest that differences in biomass allocation above or belowground may occur because of increased oxygen demands in rooting systems, greater availability of some nutrients in saturated soil, or higher nutrient uptake within the roots due to increased root length: root mass ratios (Rubio et al., 1995; Rubio and Lavado, 1999). It is also possible that plants may grow taller in deeper water to increase structural support or to access light. Regardless, we recommend that future studies examining nutrient stocks of wetland plants consider nutrient availability and water depths explicitly, as the total biomass production and allocation among tissues types is contingent on these two factors.

\section{Less Well-Studied Nutrients: Calcium and Magnesium}

A novel contribution of our work is that we considered elements beyond the commonly studied carbon, nitrogen and phosphorus. For example, calcium, and magnesium, despite their potential importance in nutrient cycling, receive much less attention in the literature (Ehrenfeld, 2010). Typha spp. had a higher concentration of calcium than the other focal species in all tissues and a higher concentration of magnesium in its stems. Consequently, the annual cattail nutrient standing stock of calcium and magnesium was significantly greater than in $P$. australis-invaded or meadow marsh. Though the difference in 
terms of magnesium was only one to two grams per meter squared, the difference in calcium standing stock was more pronounced: nearly 10-fold higher in cattail marsh than meadow marsh, for example. One possible explanation is that Typha spp. produces calcium oxalate raphide crystal bundles (Borrelli et al., 2011), which may be used for structural support, defense against herbivores, or produced as a metabolic end-product (Franceschi and Horner, 1980). In general, it appears that Typha spp. often accumulates high levels of calcium and magnesium (Olivares et al., 2002; Parzych et al., 2015). However, based on the similarity in soil calcium and magnesium concentrations, the activity of Typha spp. is not sufficient to deplete soil levels to a detectable degree. Nor is the distribution of Typha spp. restricted to areas with higher calcium or magnesium levels in the soil. This is somewhat surprising for calcium, as $19.2 \mathrm{~g} \mathrm{~m}^{-2}$ $\pm 4.5 \mathrm{SD}$ calcium in standing stock in cattail marsh is not an insignificant concentration, given the soil concentration of $6.1 \mathrm{~g}$ $\mathrm{kg}^{-1} \pm 2.0$ SD (Supplementary Materials 4). The ecological consequences of these macronutrient differences between $P$. australis-invaded and cattail marsh communities require further study.

\section{Scaling Up}

Our study scaled up from carbon and macronutrient concentrations at the tissue-level to estimate annual vegetative standing stocks per meter-squared of wetland habitat. It is important not to base assessments of carbon assimilation and nutrient retention services solely on tissue concentrations, as different tissue types typically support different carbon and nutrient levels and the ratio of tissue types can vary substantially among species. This is exemplified in our work by the higher concentration of nitrogen in $P$. australis leaves being offset by the greater proportion of leaf tissues in Typha spp. such that their nitrogen standing stock estimates are equivalent. If we had relied only on tissue concentrations, we would have drawn the erroneous conclusion that $P$. australis invasion provided enhanced nitrogen and phosphorus assimilation, regardless of which community was being replaced.

Scaling-up from tissues to standing stocks does introduce uncertainty. In our study, C. canadensis is a less dominant component of its community compared with Typha spp. and $P$. australis (Table 1). Consequently, when scaling up from tissue concentrations to marsh-level annual standing stocks, meadow marsh estimates have greater uncertainty than estimates for the cattail and $P$. australis-invaded marsh. We do not believe that this assumption undermines our conclusions, however, as recalculating carbon and macronutrient stocks based only on biomass contributed by the focal species (i.e., excluding biomass contributed by non-focal species) did not change our general conclusions. Moreover, our conclusions are supported by obvious differences in relative canopy heights and total biomass, which were significantly lower in meadow marsh than in cattail and $P$. australis-invaded marsh.

The difference in carbon, nitrogen and phosphorus assimilation between meadow marsh and invaded marsh is not negligible. Scaled up to metric tons per hectare of invaded wetland, $P$. australis-invaded marsh has an annual standing stock of carbon that is $3.87 \mathrm{~T} \mathrm{ha}^{-1}$ greater than meadow marsh (a 2-fold increase). Canada is implementing a carbon pricing system beginning in 2019 that would price one ton of $\mathrm{CO}_{2}$ or equivalent at \$16 USD, and by 2,022 plans to increase that price to $\$ 39 \mathrm{USD} / \mathrm{T} \mathrm{CO}_{2}$ (Goyal et al., 2018). After converting tons of carbon to $\mathrm{CO}_{2}$, every conversion of one hectare of meadow marsh to $P$. australis-invaded marsh would be worth $\$ 227.32$ in 2019 and \$554.10 in 2022. Currently, large portions of Lake Erie are invaded by $P$. australis, with invasion estimates ranging from 2,553 ha within Lake Erie coastal wetlands (Carson et al., 2018) to 8,233 ha invaded within $10 \mathrm{~km}$ of the American side of Lake Erie (Bourgeau-Chavez et al., 2013). Where P. australis replaced cattail marsh, this would yield no change in annual carbon stocks, but where it replaced the much rarer and biodiverse meadow marsh, we may have experienced a significant increase in carbon uptake.

While the overall amount of phosphorus in the annual vegetative standing stock of $P$. australis-invaded marshes is much smaller than the annual carbon standing stock, it still represents an almost 3-fold increase compared to meadow marsh (a difference of $0.01 \mathrm{~T} \mathrm{ha}^{-1}$ ). If we assumed that $10 \%$ of the Lake Erie coastal marsh considered $P$. australis-invaded by Carson et al. (2018) and Bourgeau-Chavez et al. (2013) was formerly meadow marsh, the annual standing stock of phosphorus would only have increased by 2.0-6.4 $\mathrm{T}$ in total. This is notably less than the phosphorus output from smaller tributaries; for example, phosphorus output from Big Creek is about $19 \mathrm{~T}$ phosphorus year $^{-1}$ (OMECC, 2017). Cleary, even a 3-fold increase in annual phosphorus stock is insufficient to make a meaningful contribution toward Lake Erie phoshorus load reduction targets, given that the current Great Lakes Water Quality Agreement between Canada and the United States of America has an interim target load for phosphorus of $11,000 \mathrm{~T}$ year $^{-1}$ for Lake Erie (United States-Canada, 2013).

Phragmites australis invaded marshes also incorporate 3-fold more nitrogen into the annual vegetative standing stock than meadow marsh (an increase of $0.12 \mathrm{~T} \mathrm{~N} \mathrm{ha}^{-1}$ ). Scaled up to the Lake Erie basin using the same estimates for the area of invasion, invasion of meadow marsh by $P$. australis would result in an 30.7-99.0 T increase in annual nitrogen standing stock. As with phosphorus, this is merely a drop in the bucket: nitrogen loading in Lake Erie was estimated at 136,000 T in 2002 (Robertson and Saad, 2013). Overall, despite extensive invasion by $P$. australis, increases in annual standing stocks of nitrogen and phosphorus are likely inconsequential for Lake Erie.

\section{Nutrient Retention vs. Nutrient Standing Stocks}

Importantly, our study focuses on the assimilation of nutrients into the vegetative standing stock of different plant communities during a single growing season but does not examine their long-term storage, which should ultimately determine nutrient retention services. In wetlands, nutrients taken up by macrophytes are quickly cycled by decomposition (Maltby and Barker, 2009). Long term retention of nutrients in plants 
varies by species and by nutrient. For example, $P$. australis litter and standing dead stems can decrease in nitrogen by approximately $40-60 \%$ and in phosphorus by $75-85 \%$ compared to the living tissue (Findlay et al., 2002). In contrast, T. angustifolia litter nitrogen concentration exceeds that of living tissues, whereas phosphorus in litter is $0-25 \%$ lower than in living tissues (Findlay et al., 2002). Calamagrostis canadensis litter can retain $70 \%$ of the nitrogen and $51 \%$ of the phosphorus it assimilated (Kao et al., 2003). This litter, typically shed by the plant each fall, then decomposes in the wetland at a rate usually dependent on the ratio of carbon to nitrogen and nitrogen to phosphorus (Enriquez et al., 1993). Because the fraction of carbon, nitrogen, and phosphorus retrieved by the plant from senescing tissues before they are shed as litter can vary among species, there could be differences in litter decomposition rates among our focal species, even though we observed no differences in carbon: nitrogen or nitrogen: phosphorus ratios among our focal species for any of the plant tissues. Importantly, our study did not address the speciation of carbon or nutrients in plant tissues. Obviously, differences in the extent or proportion of bioavailable inorganic fractions will have important ecological and biogeochemical ramifications. For example, Judd and Franceour (2019) found that ammonium in surface and pore water increased but nitrate did not change in marshes where invasive $P$. australis was controlled with herbicide. Though both of these forms of nitrogen are bioavailable to plants, increasing the dominance of ammonium over nitrate can lead to ammonium toxicity in plants and changes in soil $\mathrm{pH}$. More, if nutrient storage in invasive $P$. australis is only temporary, all the nutrients assimilated by $P$. australis may be released back into the watershed during natural senescence and decomposition in the same manner as following herbicide-caused mortality, unless plant biomass is harvested and removed for disposal by wetland managers (Carson et al., 2018). We recommend that future work establish decomposition rates and nutrient fluxes from decomposing plant litter of our three focal species to further investigate the effects of $P$. australis invasion on carbon and nutrient cycling and retention services. This future work should partition total carbon and nutrient values into organic and inorganic fractions to better inform the biogeochemical consequences of changes in stock and tissue concentrations due to $P$. australis invasion.

\section{CONCLUSION}

Phragmites australis has the capacity to assimilate carbon and nutrients at an amount and rate equal to or greater than meadow marsh communities though not more than cattail marsh. In the case of carbon stocks, invasion may even yield an economic benefit, though increases in nitrogen or phosphorus stocks where meadow marsh was invaded were negligible compared to overall nutrient loading rates and are unlikely to ameliorate nearshore eutrophication. It is also important to recognize that annual carbon and nutrient stocks offer temporary storage, and an unknown proportion will be released following senescence and decomposition of plant litter.
We caution that, as suggested by Alldred et al. (2016), invasion by $P$. australis triggers a variety of opposing changes in wetland ecosystem services that reflect trade-offs among service types. A net assessment of the effects of $P$. australis invasion must also account for the resulting loss of plant biodiversity (Keller, 2000; Tulbure et al., 2007) and associated degradation of bird (Robichaud and Rooney, 2017) and turtle habitat (Markle and Chow-Fraser, 2018). In economic terms, replacing biodiverse and rare meadow marsh habitat with $P$. australis-invaded marsh could increase carbon stocks by $3.87 \mathrm{~T}$ $\mathrm{ha}^{-1}$ and under future carbon pricing could reflect about $\$ 550$ USD ha $\mathrm{ha}^{-1}$ in carbon savings. Yet, $P$. australis invasion is a recognized threat to $25 \%$ of the 217 species at risk in Ontario (Bickerton, 2015), which exerts a much larger economic cost. For example, between 2012 and 2017, the Ontario Ministry of Natural Resources and Forestry, through the Species at Risk Stewardship Program, spent $\$ 89,826$ USD on the threatened eastern hog-nosed snake (Heterodon platirhinos) alone, which makes use of meadow marsh habitat, but not $P$. australisinvaded marsh in our study area (Ministry of Natural Resources and Forestry, 2017). Thus, the funds allocated to species at risk conservation likely dwarf any benefits in increased carbon and nutrient stocks resulting from $P$. australis invasion. These trade-offs in ecosystem services need to be weighed to arrive at effective management decisions regarding species at risk (Hershner and Havens, 2008; Hobbs et al., 2009; Davis et al., 2011), but such a comprehensive analysis is too frequently impaired by knowledge gaps like the ones we addressed in this study.

\section{DATA AVAILABILITY}

The datasets generated for this study are available on request to the corresponding author.

\section{AUTHOR CONTRIBUTIONS}

RR and SY designed the study. SY conducted the field and lab work. SY and RR analyzed the data and co-authored the manuscript.

\section{FUNDING}

This work was supported by NSERC Discovery 03846, the Ontario Ministry of Natural Resources and Forestry MNRF-W-(12)6-17, and Mitacs Accelerate IT07466 73027 in partnership with the Nature Conservancy of Canada. Funders had no role in study design, analysis, interpretation or reporting.

\section{ACKNOWLEDGMENTS}

This work could not have been completed without help from many volunteers and lab technicians; thank you Jacob Basso, Bailey Dhanani, Megan Jordan, Madison Brook, Taylor Blackwell, Lauren Koiter, and Calvin Lei. Map of our study 
area was created by Mathew Bolding and is used with permission. Thanks to Dr. Janice Gilbert, Dr. Merrin Macrae, Dr. Roland Hall, and Dr. Marcel Pinero for feedback on an early draft. Thanks also to two reviewers for their constructive comments.

\section{REFERENCES}

Agriculture and Food Laboratory University of Guelph (2017). Soil and Nutrient Laboratory Service List. Soil and Plant Nutrient Testing Laboratory, 1-4.

Alldred, M., Baines, S. B., and Findlay, S. (2016). Effects of invasive-plant management on nitrogen-removal services in freshwater tidal marshes. PLoS ONE 11:e0149813. doi: 10.1371/journal.pone.0149813

Ball, H., Jalava, J., King, T., Maynard, L., Potter, B., and Pulfer, T. (2003). The Ontario Great Lakes Coastal Weltand Atlas: A Summary of information (1983-1997). Available online at: http://longpointbiosphere.com/download/ Environment/Ontario.Great_.Lakes_.Coastal.Wetland.Atlas-2003.pdf (accessed February 14, 2018).

Barton, K. (2018). MuMIn: Multi-Model Inference. R Package Version 1.40.4. Available online at: https://cran.r-project.org/package=MuMIn

Bertness, M. D., and Coverdale, T. C. (2013). An invasive species facilitates the recovery of salt marsh ecosystems on Cape Cod. Ecology 94, 1937-1943. doi: $10.1890 / 12-2150.1$

Bhatia, M., and Goyal, D. (2014). Analyzing remediation potential of wastewater through wetland plants: a review. Environ. Prog. Sustain. Energy 33, 9-27. doi: 10.1002/ep.11822

Bickerton, H. (2015). Extent of European Common Reed (Phragmites australis ssp. australis) as a Threat to Species at Risk in Ontario. Report prepared for Natural Heritage Section Ontario Ministry of Natural Resources and Forestry. Peterborough, ON.

Bolton, R. M., and Brooks, R. J. (2010). Impact of the seasonal invasion of Phragmites australis (Common Reed) on turtle reproductive success. Chelonian Conserv. Biol. 9, 238-243. doi: 10.2744/CCB-0793.1

Borrelli, N., Fernández Honaine, M., Altamirano, S. M., and Osterrieth, M. (2011). Calcium and silica biomineralizations in leaves of eleven aquatic species of the Pampean Plain, Argentina. Aquat. Bot. 94, 29-36. doi: 10.1016/j.aquabot.2010.10.003

Bourgeau-Chavez, L. L., Kowalski, K. P., Carlson Mazur, M. L., Scarbrough, K. A., Powell, R. B., Brooks, C. N., et al. (2013). Mapping invasive Phragmites australis in the coastal Great Lakes with ALOS PALSAR satellite imagery for decision support. J. Great Lakes Res. 39, 65-77. doi: 10.1016/j.jglr.2012.11.001

Caplan, J. S., Hager, R. N., Megonigal, J. P., and Mozdzer, T. J. (2015). Global change accelerates carbon assimilation by a wetland ecosystem engineer. Environ. Res. Lett. 10, 1-12. doi: 10.1088/1748-9326/10/11/115006

Carson, B. D., Lishawa, S. C., Tuchman, N. C., Monks, A. M., Lawrence, B. A., and Albert, D. A. (2018). Harvesting invasive plants to reduce nutrient loads and produce bioenergy: an assessment of Great Lakes coastal wetlands. Ecosphere 9:e02320. doi: 10.1002/ecs2.2320

Catling, P. M., and Mitrow, G. (2011). The recent spread and potential distribution of Phragmites australis subsp. australis in Canada. Can. Field-Naturalist 125, 95-104. doi: 10.22621/cfn.v125i2.1187

Croft, M. V., and Chow-Fraser, P. (2007). Use and development of the wetland macrophyte index to detect water quality impairment in fish habitat of Great Lakes coastal marshes. J. Great Lakes Res. 33, 172-197. doi: 10.3394/03801330(2007)33[172:UADOTW]2.0.CO;2

Davis, M. A., Chew, M. K., Hobbs, R. J., Lugo, A. E., Ewel, J. J., Vermeij, G. J., et al. (2011). Don't judge species on their origins. Nature 474, 153-154. doi: $10.1038 / 474153 a$

Duke, S. T., Francoeur, S. N., and Judd, K. E. (2015). Effects of Phragmites australis invasion on carbon dynamics in a freshwater marsh. Wetlands 35, 311-321. doi: 10.1007/s13157-014-0619-x

Ehrenfeld, J. G. (2010). Ecosystem consequences of biological invasions. Annu. Rev. Ecol. Evol. Syst. 41, 59-80. doi: 10.1146/annurev-ecolsys-102209144650

\section{SUPPLEMENTARY MATERIAL}

The Supplementary Material for this article can be found online at: https://www.frontiersin.org/articles/10.3389/fenvs. 2019.00112/full\#supplementary-material

Engloner, A. I. (2009). Structure, growth dynamics and biomass of reed (Phragmites australis) - a review. Flora Morphol. Distrib. Funct. Ecol. Plants 204, 331-346. doi: 10.1016/j.flora.2008.05.001

Enriquez, S., Duarte, C., and Sand-Jensen, K. (1993). Patterns in decomposition rates among photosynthetic organisms: the importance of detritus C: N: P content. Oecologia 94, 457-471. doi: 10.1007/BF00566960

Environment and Climate Change Canada and the U.S. Environmental Protection Agency (2017). State of the Great Lakes 2017 Technical Report: Indicators to Assess the Status and Trends of the Great Lakes Ecosystem. Available online at: https://binational.net/wp-content/uploads/ 2017/09/SOGL_2017_Technical_Report-EN.pdf (accessed May 29, 2018).

Essex Region Conservation Authority (2013). Big Creek Watershed Plan. Available online at: https://essexregionconservation.ca/wp-content/uploads/2018/03/ BigCreekWatershedPlan_Final_Complete_Dec6-13.pdf (accessed July 31, 2018).

Farnsworth, E. J., and Meyerson, L. A. (2003). Comparative ecophysiology of four wetland plant species along a continuum of invasiveness. Wetlands 23, 750-762. doi: 10.1672/0277-5212(2003)023[0750:CEOFWP]2.0.CO;2

Findlay, S. E. G., Dye, S., and Kuehn, K. A. (2002). Microbial growth and nitrogen retention in litter of Phragmites australis compared to Typha angustifolia. Wetlands 22, 616-625. doi: 10.1672/0277-5212(2002)022[0616:MGANRI]2.0. $\mathrm{CO} ; 2$

Franceschi, V. R., and Horner, H. T. (1980). Calcium oxalate crystals in plants. Bot. Rev. 46, 361-427. doi: 10.1007/BF02860532

Fraser, L. H., and Karnezis, J. P. (2005). A comparative assessment of seedling survival and biomass accumulation for fourteen wetland plant species grown under minor water-depth differences. Wetlands 25, 520-530. doi: 10.1672/ 0277-5212(2005)025[0520:ACAOSS]2.0.CO;2

Freeland, J., Ciotir, C., and Kirk, H. (2013). Regional differences in the abundance of native, introduced, and hybrid Typha spp. in northeastern North America influence wetland invasions. Biol. Invasions 15, 2651-2665. doi: 10.1007/s10530-013-0481-4

Goyal, R., Gray, S., Churie Kallhauge, A., Nierop, S., Berg, T., and Leuschner, P. (2018). State and Trends of Carbon Pricing 2018.

Graham, S. A., and Mendelssohn, I. A. (2016). Contrasting effects of nutrient enrichment on below-ground biomass in coastal wetlands. J. Ecol. 104, 249-260. doi: 10.1111/1365-2745.12498

Greenberg, D. A., and Green, D. M. (2013). Effects of an invasive plant on population dynamics in toads. J. Soc. Conserv. Biol. 27, 1049-1057. doi: $10.1111 /$ cobi.12078

Grutters, B. M. C., Pollux, B. J. A., Verberk, W. C. E. P., and Bakker, E. S. (2015). Native and non-native plants provide similar refuge to invertebrate prey, but less than artificial plants. PLoS ONE 10:e0124455. doi: 10.1371/journal.pone. 0124455

Gumbricht, T. (1993). Nutrient removal processes in freshwater submersed macrophyte systems. Ecol. Eng. 2, 1-30. doi: 10.1016/0925-8574(93)90024-A

Hershner, C., and Havens, K. J. (2008). Managing invasive aquatic plants in a changing system: strategic consideration of ecosystem services. Conserv. Biol. 22, 544-550. doi: 10.1111/j.1523-1739.2008.00957.x

Hirtreiter, J. N., and Potts, D. L. (2012). Canopy structure, photosynthetic capacity and nitrogen distribution in adjacent mixed and monospecific stands of Phragmites australis and Typha latifolia. Plant Ecol. 213, 821-829. doi: 10.1007/s11258-012-0044-2

Hobbs, R. J., Higgs, E., and Harris, J. A. (2009). Novel ecosystems: implications for conservation and restoration. Trends Ecol. Evol. 24, 599-605. doi: 10.1016/j.tree.2009.05.012

Jarvie, H. P., Johnson, L. T., Sharpley, A. N., Smith, D. R., Baker, D. B., Bruulsema, T. W., et al. (2017). Increased soluble phosphorus loads to Lake 
Erie: unintended consequences of conservation practices? J. Environ. Qual. 46, 123-132. doi: 10.2134/jeq2016.07.0248

Judd, K., and Franceour, S. N. (2019). Short-term impacts of Phragmites management on nutrient budgets and plant communities in Great Lakes coastal freshwater marshes. Wetlands Ecol. Manag. 27, 55-74. doi: 10.1007/s11273-018-9643-6

Jung, J. A., Rokitnicki-Wojcik, D., and Midwood, J. D. (2017). Characterizing past and modelling future spread of Phragmites australis ssp. australis at Long Point Peninsula, Ontario, Canada. Wetlands 37, 961-973. doi: 10.1007/s13157-017-0931-3

Kao, J. T., Titus, J. E., and Zhu, W.-X. (2003). Differential nitrogen and phosphorus retention by five wetland plant species. Wetlands 23, 979-987. doi: 10.1672/ 0277-5212(2003)023[0979:DNAPRB]2.0.CO;2

Keller, B. E. M. (2000). Plant diversity in Lythrum, Phragmites, and Typha marshes, Massachusetts, U.S.A. Wetl. Ecol. Manag. 8, 391-401. doi: 10.1023/A:1026505817409

Kirk, H., Connolly, C., and Freeland, J. R. (2011). Molecular genetic data reveal hybridization between Typha angustifolia and Typha latifolia across a broad spatial scale in eastern North America. Aquat. Bot. 95, 189-193. doi: 10.1016/j.aquabot.2011.05.007

Kiviat, E. (2013). Ecosystem services of Phragmites in North America with emphasis on habitat functions. AoB Plants 5:plt008. doi: 10.1093/aobpla/plt008

Kopf, R. K., Nimmo, D. G., Humphries, P., Baumgartner, L. J., Bode, M., Bond, N. R., et al. (2017). Confronting the risks of large-scale invasive species control. Nat. Ecol. Evol. 1, 172. doi: 10.1038/s41559-017-0172

Kvet, J., Pokorny, J., and Cizkova, H. (2008). Carbon accumulation by macrophytes of aquatic and wetland habitats with standing water. Proc. Natl. Acad. Sci. India Sect. B Biological Sci. 78, 91-98. Available online at: https://www.researchgate. net/publication/282684167

Larkin, D. J., Freyman, M. J., Lishawa, S. C., Geddes, P., and Tuchman, N. C. (2012). Mechanisms of dominance by the invasive hybrid cattail Typha $\times$ glauca. Biol. Invasions 14, 65-77. doi: 10.1007/s10530-011-0059-y

Li, H., Liu, Y., Li, J., Zhou, X., and Li, B. (2016). Dynamics of litter decomposition of dieback Phragmites in Spartina-invaded salt marshes. Ecol. Eng. 90, 459-465. doi: $10.1016 /$ j.ecoleng.2016.01.012

Lombard, K. B., Tomassi, D., and Ebersole, J. (2012). Long-term management of an invasive plant: lessons from seven years of Phragmites australis control. Northeast Nat. 19, 181-193. doi: 10.1656/045.019.s614

Mal, T. K., and Narine, L. (2004). The biology of Canadian weeds. 129. Phragmites australis (Cav.) Trin. ex Steud. Can. J. Plant Sci. 84, 365-396. doi: 10.4141/P01-172

Maltby, E., and Barker, T. (2009). The Wetlands Handbook. 1st Edn. West Sussex: Wiley-Blackwell. Available online at: https://www.amazon.ca/ Wetlands-Handbook-Edward-Maltby/dp/0632052554

Markle, C. E., Chow-fraser, G., and Chow-fraser, P. (2018). Long-term habitat changes in a protected area: implications for herpetofauna habitat management and restoration. PLoS ONE 13, 1-15. doi: 10.1371/journal.pone.0192134

Markle, C. E., and Chow-Fraser, P. (2018). Effects of European common reed on Blanding's turtle spatial ecology. J. Wildl. Manag. 82, 857-864. doi: 10.1002/jwmg. 21435

Martin, L. J., and Blossey, B. (2013). The runaway weed: costs and failures of Phragmites australis management in the USA. Estuar. Coasts 36, 626-632. doi: 10.1007/s12237-013-9593-4

Meyer, S. W., Badzinski, S. S., Petrie, S. A., and Ankney, C. D. (2010). Seasonal abundance and species richness of birds in Common Reed habitats in Lake Erie. J. Wildl. Manage. 74, 1559-1567. doi: 10.1111/j.1937-2817.2010.tb01284.x

Middleton, B. A., Van Der Valk, A. G., and Davis, C. B. (2015). Responses to water depth and clipping of twenty-three plant species in an Indian monsoonal wetland. Aquat. Bot. 126, 38-47. doi: 10.1016/j.aquabot.2015.06.004

Miller, R. C., and Zedler, J. B. (2013). Responses depth of native and invasive wetland plants to hydroperiod and water. Plant Ecol. 167, 57-69. doi: 10.1023/A:1023918619073

Minchinton, T. E., and Bertness, M. D. (2003). Disturbance-mediated competition and the spread of Phragmites australis in a coastal marsh. Ecol. Appl. 13, 1400-1416. doi: 10.1890/02-5136

Ministry of Natural Resources and Forestry (2017). Five-year Review of Progress towards the Protection and Recovery of Ontario's Species at Risk 2017.
Available online at: https://files.ontario.ca/2017_5yrsummary_final-22-02-18. pdf (accessed September 13, 2018).

Ministry of Natural Resources and Forestry (2018). Get Natural Heritage Information. Queen's Print. Ontario, 2012-17. Available online at: https://www. ontario.ca/page/get-natural-heritage-information (accessed January 10, 2017).

Neill, C. (1992). Comparison of soil coring and ingrowth methods for measuring belowground production. Ecology 73, 1918-1921. doi: 10.2307/1940044

Norkko, J., Reed, D. C., Timmermann, K., Norkko, A., Gustafsson, B. G., Bonsdorff, E., et al. (2012). A welcome can of worms? Hypoxia mitigation by an invasive species. Glob. Chang. Biol. 18, 422-434. doi: 10.1111/j.1365-2486.2011.02513.x

Olivares, E., Vizcaíno, D., and Gamboa, A. (2002). Mineral nutrition of three aquatic emergent macrophytes in a managed wetland in Venezuela. J. Plant Nutr. 25, 475-496. doi: 10.1081/PLN-120003377

OMECC (2017). Partnering in Phosphorus Control: Achieving Phosphorus Reductions in Lake Erie from Canadian sources. The Canada-Ontario Draft Action Plan. Available online at: http://www.downloads.ene.gov.on.ca/ envision/env_reg/er/documents/2017/012-9971 ENG.pdf

Ouellet-Plamondon, C. M., Brisson, J., Comeau, Y. (2004). "Effect of macrophyte species on subsurface flow wetland performance in cold climate," in Proceedings of the 2004 Self-Sustaining Solutions for Streams, Wetlands, and Watersheds Conference, 8-15. Available online at: http://www.scopus. com/inward/record.url?eid=2-s2.0-27844525643\&partnerID=40\&md5= 2eb4c1676aeeb9934759e44e05506efb

Parzych, A. E., Cymer, M., Jonczak, J., and Szymczyk, S. (2015). The ability of leaves and rhizomes of aquatic plants to accumulate macro- and micronutrients. $J$. Ecol. Eng. 16, 198-205. doi: 10.12911/22998993/2956

Powelson, R. A., and Lieffers, V. J. (1992). Effect of light and nutrients on biomass allocation in Calamagrostis canadensis. Ecography 15, 31-36. doi: 10.1111/j.1600-0587.1992.tb00005.x

Quirion, B., Simek, Z., Dávalos, A., and Blossey, B. (2018). Management of invasive Phragmites australis in the Adirondacks: a cautionary tale about prospects of eradication. Biol. Invasions 20, 59-73. doi: 10.1007/s10530-017-1513-2

R Core Team (2016). R: A Language and Environment for Statistical Computing. Available online at: https://www.r-project.org/

Reid, K. (1998). Soil Fertility Handbook. OMAFRA Publication. Available online at: http://www.omafra.gov.on.ca/english/crops/pub611/pub611.pdf (accessed May 29, 2018).

Robertson, D. M., and Saad, D. A. (2013). Nutrient inputs to the Laurentian Great Lakes by source and watershed estimated using SPARROW watershed models. J. Am. Water Resour. Assoc. 49, 725-734. doi: 10.1111/jawr.12060

Robichaud, C. D., and Rooney, R. C. (2017). Long-term effects of a Phragmites australis invasion on birds in a Lake Erie coastal marsh. J. Great Lakes Res. 43, 141-149. doi: 10.1016/j.jglr.2017.03.018

Rong, M., Xinhou, Z., and Changchun, S. (2014). Effects of nitrogen addition on plant functional traits in freshwater wetland of Sanjiang Plain, Northeast China. Chin. Geogr. Sci. 24, 674-681. doi: 10.1007/s11769-014-0691-4

Rooth, J. E., Stevenson, J. C., and Cornwell, J. C. (2003). Increased sediment accretion rates following invasion by Phragmites australis: the role of litter. Estuaries 26, 475-483. doi: 10.1007/BF02823724

Rothman, E., and Bouchard, V. (2007). Regulation of carbon processes by macrophyte species in a Great Lakes coastal wetland. Wetlands 27, 1134-1143. doi: 10.1672/0277-5212(2007)27[1134:ROCPBM]2.0.CO;2

Rubio, G., Casasola, G., and Lavado, R. S. (1995). Adaptations and biomass production of two grasses in response to waterlogging and soil nutrient enrichment. Oecologia 102, 102-105. doi: 10.1007/BF00333316

Rubio, G., and Lavado, R. S. (1999). Acquisition and allocation of resources in two waterlogging-tolerant grasses. New Phytol. 143, 539-546. doi: 10.1046/j.1469-8137.1999.00482.x

Sax, D. F., and Gaines, S. D. (2003). Species diversity: from global decreases to local increases. Trends Ecol. Evol. 18, 561-566. doi: 10.1016/S0169-5347(03)00224-6

Schlaepfer, M. A., Sax, D. F., and Olden, J. D. (2011). The potential conservation value of non-native species. Conserv. Biol. 25, 428-437. doi: 10.1111/j.1523-1739.2010.01646.x

Schlaepfer, M. A., Sax, D. F., and Olden, J. D. (2012). Toward a more balanced view of non-native species. Conserv. Biol. 26, 1156-1158. doi: 10.1111/j.1523-1739.2012.01948.x 
Simard, R. (1993). "Ammonium acetate-extractable elements," in Soil Sampling and Methods of Analysis, Canadian Society of Soil Science, ed M. R. Carter (Boca Raton, FL: Lewis Publishers), 39-42.

Simberloff, D. (2011). How common are invasion-induced ecosystem impacts? Biol. Invasions 13, 1255-1268. doi: 10.1007/s10530-011-9956-3

Swearingen, J., Saltonstall, K., and Tilley, D. (2012). Phragmites Field Guide: Distinguishing Native and Exotic Forms of Common Reed (Phragmites australis) in the United States. USDA Natural Resources Conservation Service Technical Note TN Plant Materials No. 56. Available online at: https://www.nrcs.usda. gov/Internet/FSE_PLANTMATERIALS/publications/idpmctn11494.pdf

Tho, B. T., Sorrell, B. K., Lambertini, C., Eller, F., and Brix, H. (2016). Phragmites australis: how do genotypes of different phylogeographic origins differ from their invasive genotypes in growth, nitrogen allocation and gas exchange? Biol. Invasions 18, 2563-2576. doi: 10.1007/s10530-016-1158-6

Tulbure, M. G., and Johnston, C. A. (2010). Environmental conditions promoting non-native Phragmites australis expansion in Great Lakes coastal wetlands. Wetlands 30, 577-587. doi: 10.1007/s13157-010-0054-6

Tulbure, M. G., Johnston, C. A., and Auger, D. L. (2007). Rapid invasion of a Great Lakes coastal wetland by non-native Phragmites australis and Typha. J. Great Lakes Res. 33, 269-279. doi: 10.3394/0380-1330(2007)33[269:RIOAGL]2. $0 . \mathrm{CO} ; 2$

United States-Canada (2013). Great Lakes Water Quality Agreement. Available online at: http://ijc.org/files/tinymce/uploaded/GLWQA2012.pdf (accessed August 1, 2018).

Vitule, J. R. S., Freire, C. A., Vazquez, D. P., Nuñez, M. A., and Simberloff, D. (2012). Revisiting the potential conservation value of non-native species. Conserv. Biol. 26, 1153-1155. doi: 10.1111/j.1523-1739.2012.01950.x

Watson, S. B., Miller, C., Arhonditsis, G., Boyer, G. L., Carmichael, W., Charlton, M. N., et al. (2016). The re-eutrophication of Lake Erie: harmful algal blooms and hypoxia. Harmful Algae 56, 44-66. doi: 10.1016/j.hal.2016. 04.010

Wetzel, P. R., and van der Valk, A. G. (2005). The biomass and nutrient levels of Calamagrostis canadensis and Carex stricta under different hydrologic and fungicide regimes. Can. J. Bot. 83, 124-130. doi: 10.1139/b04-142

Wilcox, K. L., Petrie, S. A., Maynard, L. A., and Meyer, S. W. (2003). Historical distribution and abundance of Phragmites australis at Long Point, Lake Erie, Ontario. J. Great Lakes Res. 29, 664-680. doi: 10.1016/S0380-1330(03)70469-9

Windham, L. (2001). Comparison of biomass production and decomposition between Phragmites australis (Common Reed) and Spartina patens (Salt Hay Grass) in brackish tidal marshes of New Jersey, USA. Wetlands 21, 179-188. doi: 10.1672/0277-5212(2001)021[0179:COBPAD]2.0.CO;2

Windham, L., and Ehrenfeld, J. G. (2013). Net impact of a plant invasion on nitrogen-cycling processes within a brackish tidal marsh. Ecol. Appl. 13, 883-897. doi: 10.1890/02-5005

Zedler, J. B., and Kercher, S. (2005). Wetland resources: status, trends, ecosystem services, and restorability. Annu. Rev. Environ. Resour. 30, 39-74. doi: 10.1146/annurev.energy.30.050504.144248

Conflict of Interest Statement: The authors declare that the research was conducted in the absence of any commercial or financial relationships that could be construed as a potential conflict of interest.

Copyright $\odot 2019$ Yuckin and Rooney. This is an open-access article distributed under the terms of the Creative Commons Attribution License (CC BY). The use, distribution or reproduction in other forums is permitted, provided the original author(s) and the copyright owner(s) are credited and that the original publication in this journal is cited, in accordance with accepted academic practice. No use, distribution or reproduction is permitted which does not comply with these terms. 